\section{Eiríkur Steingrímsson}

sameindalifræðingur

Lífefna- og sameindaliffræðistofu,

Lífvísindasetri,

læknadeild Háskóla Íslands

\title{
Dægurklukkan og Nóbelsverðlaunin í lífeðlis- og læknisfræði 2017
}

Í ár voru Nóbelsverðlaunin í lífeðlis- og læknisfræði veitt premur Bandaríkjamönnum, peim Jeffrey C. Hall, Michael Rosbash og Michael W. Young, fyrir rannsóknir peirra á erfða- og sameindalíffræði dægurklukkunnar. Jeffrey Hall og Michael Rosbash eru báðir prófessorar við Brandeis-háskólann í Massachusetts en Michael Young er prófessor við Rockefeller-háskólann í New York. Allir notuðu peir ávaxtafluguna Drosophila melanogaster til rannsókna sinna.

Flestar lífverur hafa innri 24-tíma klukku sem stjórnar svefni og vöku en einnig annarri starfsemi líkamans svo sem blóðprýstingi, efnaskiptum og tjáningu gena. Vegna klukkunnar eru lífverur undirbúnar fyrir birtubreytingar pær sem fylgja snúningi jarðar. Fyrstu sannfærandi tilraunirnar sem bentu til að lífklukkan væri raunveruleg voru gerðar af frönskum stjarnfræðingi sem sýndi árið 1729 að mímósur, sem opna laufin á daginn og loka peim aftur á nóttunni, héldu peim takti pótt pær væru hafðar í myrkri. •að var pó ekki fyrr en rúmlega 200 árum síðar, eða 1971, sem fyrstu vísbendingar fundust um að petta fyrirbæri væri skráð í erfðamengið pegar peir Ronald Konopka og Seymour Benzer fundu stökkbreytingar í einu og sama geninu í ávaxtaflugum sem hafði áhrif á lífklukkuna og voru annaðhvort með enga, styttri eða lengri dægursveiflu. ${ }^{1}$ Genið nefndu peir period.

Jeff Hall og Michael Rosbash eru jafnaldrar og voru báðir ráđnir til Brandeis-háskóla árið 1974 og urðu fljótt vinir og samstarfsfélagar. Hall hafði verið nýdoktor hjá Seymour Benzer og vildi skilja hvernig dægurklukkan virkaði. Hann hafði mikla reynslu í erfðafræði ávaxtaflugunnar en vissi lítið um sameindalíffræði enda var hún rétt að verða til á pessum tíma. Rosbash, sem kunni aðferðir sameindalíffræðinnar, stakk upp á pví eftir körfuboltaleik eitt kvöldið að peir mundu vinna saman að pví að einangra period-genið. Peir gerðu pað og birtu grein um niðurstöður rannsókna sinna í tímaritinu Cell árið $1984 .{ }^{2}$

Priðji Nóbelsverðlaunahafinn, Michael Young, var nýdoktor á rannsóknastofu David Hogness við Stanford-háskóla um pað leyti sem DNA-klónun var að koma fram. Hann hafði lengi haft áhuga á vinnu Seymour Benzers með period-genið, og skömmu eftir að hann hóf störf við Rockefeller-háskólann tókst honum einnig að einangra genið og birti niðurstöður sínar í tímaritinu Nature, ${ }^{3}$ sama ár og Hall og Rosbash birtu sína grein. Næstu ár fóru í að greina tjáningu, hlutverk og starfsemi gensins. Árið 1990 birtu Hall og Rosbash mikilvæga grein par sem peir lýstu pví hvernig tjáning period mRNA-sameindarinnar sveiflast með 24 tíma reglu par sem aðeins sést einn toppur í tjáningu á sólarhring. ${ }^{4}$ Stökkbreytingarnar sem Benzer hafði lýst annaðhvort styttu eða lengdu tímabilið milli peirra. Peir settu pví fram líkan sem gerir ráð fyrir neikvæðri endurgjöf (negative feedback) par sem aukin tjáning á Period-próteininu veldur pví að tjáningin á geninu lækkar aftur. Nú, tæplega 30 árum síðar hefur petta líkan í stórum dráttum reynst rétt. Peir Hall, Rosbash og Young hafa leitt rannsóknir á dægurklukkunni og lagt mest til hennar. Period-próteinið reyndist vera stjórnprótein sem binst DNA-inu og hefur áhrif á tjáningu gena. Neikvæða endurgjöfin felst í pví að Period, ásamt öðru próteini sem nefnist Timeless, mynda tvennd sem binst stjórnsvæði period- og timeless-genanna og hindrar tjáningu peirra. Par sem stöðugleika pessara próteina er líka stjórnað, meðal annars með tilhlutan ljóss, verða til pessar 24 tíma sveiflur í magni period og timeless afurðanna. Peir sem vilja kynna sér nánar hvernig klukkan virkar í ávaxtaflugunni geta skoðað myndband á vefsíðunni hhmi.org/ biointeractive/drosophila-molecular-clock-model par sem Michael Rosbash útskýrir hvernig petta virkar. Svipað kerfi stjórnar klukkunni í mönnum par sem sömu gen og prótein koma við sögu. Við verðum kannski mest vör við líkamleg og andleg áhrif dægurklukkunnar pegar við ferðumst milli tímabelta og vaktavinnufólk, til dæmis læknar, pekkja áhrif hennar mæta vel. Klukkan hefur áhrif á svefn og getur pannig haft áhrif á heilsu manna.

Рað er áhugavert að Nóbelsverðlaunin í ár eru veitt fyrir áratuga rannsóknir á dægurklukkunni í ávaxtaflugunni, par sem fyrstu niðurstöðurnar eru yfir 30 ára gamlar. Jerome Groopman sem skrifar í The New Yorker (newyorker.com/tech/elements/the-real-message-of-the-2017-nobel-prize-in-physiology-medicine) telur að petta sé ekki tilviljun heldur sé Nóbelsnefndin að senda skilaboð um að grunnrannsóknir séu ennpá mikilvægar. Hann bendir á að verðlaunin í fyrra voru veitt fyrir grunnrannsóknir á sjálfsáti ${ }^{5}$ og skilaboðin séu pví pau að pað sé enn mikilvægt að styðja við rannsóknir par sem takmarkið er einfaldlega skilningur á lífinu og áhrifum umhverfisins á pað. Pessi skilaboð eru áhugaverð á tímum pegar mikilvægi pekkingar og vísinda er víða dregið í efa.

\section{Heimildir}

1. Konopka RJ, Benzer S. Clock mutants of Drosophila melanogaster. Proc Nat Acad Sci USA 1971 68: 2112-6.

2. Reddy P, Zehring WA, Wheeler DA, Pirrotta V, Hadfield, Hall HC, et al. Molecular analysis of the period locus in Drosophila melanogaster and identification of a transcript involved in biological rythms. Cell 1984; 36: 701-10.

3. Bargiello TA, Jackson FR, Young MW. Restoration of circadian behavioural rhythms by gene transfer in Drosophila. Nature 1984; 312: 752-4.

4. Hardin PE, Hall JC, Rosbash M. Feedback of the Drosophila period gene product on circadian cycling of its messengar RNA levels. Nature 1990; 343: 536-40.

5. Ögmundsdóttir MH. Nóbelsverðlaunin í læknavísindum í ár endurspegla mikilvægi sorphirðu og endurvinnslu. Læknablaðið 2016; 102: 481. 